\title{
GLIPR2 wt Allele
}

National Cancer Institute

\section{Source}

National Cancer Institute. GLIPR2 wt Allele. NCI Thesaurus. Code C54265.

Human GLIPR2 wild-type allele is located within 9p13-p12 and is approximately $27 \mathrm{~kb}$ in length. This allele, which encodes golgi-associated plant pathogenesis-related protein, is involved in immune responses. 